\title{
THE DISAPPEARANCE RATE OF COLLOIDAL RADIOGOLD FROM THE CIRCULATION AND ITS APPLICATION TO THE ES- TIMATION OF LIVER BLOOD FLOW IN NORMAL AND CIRRHOTIC SUBJECTS
}

\author{
By HERBERT VETTER, RUDOLF FALKNER, AND ANTON NEUMAYR \\ (From the Second Medical University Clinic, University of Vienna, Vienna, Austria)
}

(Submitted for publication April 7, 1954 ; accepted August 5, 1954)

The bromsulphalein method of estimating liver blood flow in man first introduced by Bradley, Ingelfinger, Bradley, and Curry (1) has proved to be a very useful tool in the hands of various workers. Though there is not complete agreement as to the question of extrahepatic dye loss and the problem of a single hepatic vein sample not being entirely representative of all the blood leaving the liver, a considerable amount of information has been gathered by studying the state of liver circulation in normal and diseased subjects and its alterations produced by exercise, posture, anesthesia, and various drugs. However, the technic employed is by no means a simple one and requires the team work of several highly trained people.

Very recently, an entirely different method has been applied to the study of hepatic circulation. It is based on the assumption that the phagocytes of liver and spleen are highly efficient in removing colloid particulate matter from the blood stream in a single passage. If this assumption holds true, then the disappearance rate of this colloid from the circulation would essentially be a parameter of liver blood flow. Since the liver and spleen are in series with each other and since the bone marrow takes up only minimal amounts of this colloid, it was felt by Sheppard, Jordan, and Hahn (2) that it should be possible to calculate liver blood flow from the disappearance rate constant as the fraction of blood volume perfusing the liver per unit time. This idea has been put into practice by Dobson, Warner, Finney, and Johnston (3) who used chromic phosphate labeled with radiophosphorus as the particulate matter. However, this method again appears not to be as simple as one would want it to be for a routine diagnostic procedure. The preparation of a chromic phosphate colloid of suitable particle size is quite a laborious procedure, and the determination of the disappearance rate itself involves the withdrawal of serial blood samples which, to the patient, results in the loss of a considerable amount of blood.

A further simplification of the estimation of liver blood flow in man would, therefore, be afforded by using a colloid readily at hand, and by labeling it with a $\gamma$-emitting isotope which would permit external determination of the disappearance rate without the need for withdrawing blood samples. The present paper reports some results obtained with colloidal radioactive gold $\left(\mathrm{Au}^{108}\right)$ used as the particulate matter, the measurements being carried out by means of a counter placed between the calves of the subject. Various factors which might influence the reliability and accuracy of this method as well as some of the questions which have to be answered before the transformation of colloid disappearance rates into terms of liver blood flow could be considered to be justified, will be discussed. Some preliminary results have been published elsewhere (4).

\section{METHODS}

Colloidal radioactive gold. Colloidal $\mathrm{Au}^{\mathrm{m}}$ was obtained from A.E.R.E., Harwell, England, as a 0.5 per cent $(\mathrm{W} / \mathrm{V})$ solution with a specific activity of between 10 and $20 \mathrm{mc}$. per $\mathrm{ml}$. The average particle size of this preparation, estimated by electron microscopic observation, is about $250 \AA$ and the scatter around the mean is very small. 1 After suitable dilution with sterile pyrogen-free isotonic saline, between 25 and $250 \mu \mathrm{gm}$. of colloidal gold containing between 50 and $100 \mu \mathrm{c}$. Au ${ }^{100}$ were injected intravenously. Care was taken to avoid any effect of dilution on colloid stability.

Blood samples. In the early series of experiments which were done in order to obtain some information on the reliability of external measurements and on the influence of mixing of the colloid particles within the cir-

1 We wish to thank Mr. F. Hudswell, Chemist in Charge of Chemical Production Group, Isotope Division, A.E.R.E., Harwell, England, for kindly providing this information. 
culating blood on the disappearance rate, it was necessary to withdraw serial blood samples for determination of radioactivity and $\mathrm{T}-1824$ concentration. An indwelling needle was placed into the brachial artery of the other arm and was left there throughout the experiment. By removing the stylet, $6.0 \mathrm{ml}$. samples were taken into heparinized tubes at the following times after injection: $1,2,3,4,5,7,9,12,15,20,25,35,45$, and 60 minutes.

Determination of radioactivity. The radioactivity of the blood samples was determined in the liquid counter designed by Veall (5), $1.0 \mathrm{ml}$. of blood having been hemolyzed and diluted with $10 \mathrm{ml}$. of tap water. External measurements were done using an unshielded lead cathode $\gamma$-counter (20th Century G.10.Pb) placed between the calves of the patient. In preliminary experiments the increase in the background count due to the accumulation of the radiogold in the liver and spleen was found to be negligible. With both methods, the absolute counting rate was always higher than twice the background even at the end of one hour following injection.

Plasma volume. Between 10 and $15 \mathrm{mgm}$. of purified T-1824 (I.C.I.) as a 0.075 per cent (W/V) solution were injected simultaneously with the radiogold injection into another vein of the same arm. Dye concentrations were determined with a Zeiss photoelectric spectrophotometer at a wave length of $6200 \AA$. In the early series of patients where serial blood samples were taken, the values obtained were plotted on semilogarithmic paper and extrapolated back to time zero. In the later series where the colloid disappearance rate was determined by external counting, only a ten-minute sample was withdrawn and a 1.5 per cent loss of dye was assumed to have occurred during this period. The standard amount of dye was delivered to a blank sample by a carefully calibrated $50 \mu$ l. pipet.

Hematocrit. Two $1 \mathrm{ml}$. samples of heparinized blood taken simultaneously with the blank samples, were pipeted into Wintrobe tubes with a $2 \mathrm{~mm}$. bore. They were spun for $30 \mathrm{~min}$ at $3000 \mathrm{rpm}$. in an ordinary centrifuge applying a force of $1500 \times$ gravity. A correction for the amount of plasma trapped between the red cells was applied to the mean of both readings according to the graph published by Chaplin and Mollison (6).

Blood volume. Total blood volume was calculated from the plasma volume and the corrected venous hematocrit after the latter had been further corrected for the uneven distribution of red cells and plasma within the circulation by applying a correction factor of 0.91 . This factor was shown by Chaplin, Mollison, and Vetter (7) to be valid over a wide range of hematocrits.

\section{RESULTS}

\section{Calculation of the disappearance rate constant}

When plotted on semilogarithmic paper the actual disappearance curve of the colloidal gold ap- pears to be the composite of a series of simple exponential curves. The first, i.e., fastest, component of this curve is obtained by the usual graphical separation of the single components, and only this component is taken for calculation of the disappearance rate constant $\mathbf{k}$. A thorough description of this procedure has been given by Dobson and Jones (8) as well as in a previous paper by the present authors (4).

Theoretically, mixing of the injected particulate matter within the circulating blood should be essentially completed before the values obtained are used for the determination of the half time of disappearance. It appears from the $\mathrm{T}-1824$ curves that this is not always the case. Dobson, Warner, Finney, and Johnston (3) have tried to overcome this difficulty by expressing the sample data as a ratio of colloid concentration over dye concentration, thus accounting for mixing influences which may occur during the first few minutes following injection.

The value of $\mathbf{k}$ obtained by using this ratio may sometimes appreciably differ in either direction from the rate constant calculated from the colloid disappearance curve alone. However, on the average this difference is almost negligible, and this has been shown to be true even in cases with impaired liver function (4). Therefore, it was felt that the serial determination of $\mathrm{T}-1824$ concentrations is not essential for the accuracy of this method and accordingly, all values of the rate constant $\mathrm{k}$ in the accompanying tables should be understood as simple colloid disappearance rate constants.

\section{The validity of external measurements}

In five subjects the disappearance rate constants obtained from blood samples and by ex-

TABLE I

Comparison of disappearance rates obtained from blood samples and from the calves

\begin{tabular}{|c|c|c|c|c|c|}
\hline Case & Name & Diagnosis & 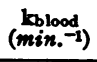 & $\underset{(\min .-1)}{\text { Konlres }}$ & $k_{0 a} / k_{b 1}$ \\
\hline $\begin{array}{l}1 \\
2 \\
3 \\
4 \\
5\end{array}$ & $\begin{array}{l}\text { SCHI } \\
\text { LAM } \\
\text { KOR } \\
\text { ALT } \\
\text { ALB }\end{array}$ & $\begin{array}{l}\text { Cirrhosis } \\
\text { Hepatitis } \\
\text { Cardiac failure } \\
\text { Hypertension } \\
\text { Normal }\end{array}$ & $\begin{array}{l}.066 \\
.141 \\
.151 \\
.190 \\
.248\end{array}$ & $\begin{array}{l}.065 \\
.141 \\
.153 \\
.201 \\
.267\end{array}$ & $\begin{array}{l}.985 \\
1.000 \\
1.013 \\
1.053 \\
1.079\end{array}$ \\
\hline \multicolumn{3}{|c|}{ Mean } & & & 1.027 \\
\hline
\end{tabular}


ternal measurement have been compared (Table I). On the average, the constants determined between the calves were slightly higher than those obtained from blood samples. However, this difference was only 2.7 per cent and cannot be considered to be significant. Thus, external measurement is regarded to be a satisfactory method of determining the removal rate of the colloidal gold from the blood stream. Moreover, the values obtained are representative for both arterial and venous blood concentrations and, therefore, the differences which have been shown by Dobson, Warner, Finney, and Johnston (3) to exist between both concentrations due to mixing influences, are eliminated.

\section{Reproducibility of results}

In another group of five subjects a second estimation of the disappearance rate constant was done one hour after the first, with a dose of colloidal gold not exceeding $100 \mu \mathrm{gm}$. At this time, the background count between the calves due to the radioactive material still circulating in the blood and presumably consisting of very small particles, was considered to be fairly stable. It had been found in preliminary experiments that during the second hour following injection the disappearance rate of these particles has never been higher than a few per cent per hour. There was, on the average, no difference between both series (Table II). The differences in individual cases have been very small. It is, therefore, concluded that the reproducibility of the results obtained with this method is satisfactory.

\section{Effects of quantity of particulate material injected}

In a further group of five subjects the disappearance rate constant was determined by in-

TABLE II

Results of repeated measurements between the calves

\begin{tabular}{|c|c|c|c|c|c|}
\hline Case & Name & Diagnods & $\left.{ }_{(\min }^{k_{1}-1}\right)$ & ${ }_{\left(m i x_{0}-1\right.}^{k_{2}}$ & $k_{2} / k_{1}$ \\
\hline $\begin{array}{l}1 \\
2 \\
3 \\
4 \\
5\end{array}$ & $\begin{array}{l}\text { BUR } \\
\text { FRA } \\
\text { NOT } \\
\text { WUD } \\
\text { WAW }\end{array}$ & $\begin{array}{l}\text { Posthepatitis } \\
\text { Posthepatitis } \\
\text { Normal } \\
\text { Mitral stenosis } \\
\text { Normal }\end{array}$ & $\begin{array}{l}.178 \\
.216 \\
.224 \\
.235 \\
.292\end{array}$ & $\begin{array}{l}.182 \\
.210 \\
.224 \\
.243 \\
.286\end{array}$ & $\begin{array}{r}1.022 \\
.972 \\
1.000 \\
1.034 \\
.979\end{array}$ \\
\hline \multicolumn{2}{|c|}{ Mean } & & & & 1.001 \\
\hline
\end{tabular}

TABLE III

Effects of increasing the quantity of stable colloidal gold on the disappearance rate

\begin{tabular}{cllrrr}
\hline \hline Case & Name & \multicolumn{1}{c}{ Diagnosis } & $\begin{array}{c}\mathbf{k}_{1} \\
\left(\min .^{-1}\right)\end{array}$ & $\begin{array}{c}\mathbf{k}_{2} \\
\left(\min .^{-1}\right)\end{array}$ & $\mathbf{k}_{2} / \mathbf{k}_{1}$ \\
\hline 1 & KOR & Cardiac failure & $.152^{*}$ & $.132 \dagger$ & .868 \\
2 & ALT & Hypertension & $.195^{*}$ & $.139 \dagger$ & .713 \\
3 & SIM & Normal & $.276^{*}$ & $.243 \dagger$ & .881 \\
4 & BER & Normal & $.252^{*}$ & $.256 \ddagger$ & 1.016 \\
5 & TOR & Normal & $.314^{*}$ & $.309 \ddagger$ & .984 \\
\hline
\end{tabular}

* Amount injected: $0.25 \mathrm{mgm}$.

t Amount injected: $1.50 \mathrm{mgm}$.

† Amount injected: $0.50 \mathrm{mgm}$.

jecting $250 \mu \mathrm{gm}$. of colloidal radiogold. In three of these, the experiment was repeated after one hour with six times this amount of material. In two cases, twice the amount was given. Removal of $\mathrm{Au}^{198}$ on second injection was definitely lowered in the first three cases, whereas in the other two cases no significant difference was observed (Table III). This "overloading" effect was not to be expected since Dobson and Jones in their experiments on mice (8) had used comparatively much larger quantities of chromic phosphate.

It is, however, conceivable that the magnitude of this "overloading" effect does not depend as much on the weight of the particulate material injected as on the number of particles. Since the preparation used in the present experiments contained, presumably, at least ten times as many particles per unit weight as the chromic phosphate preparation used by Dobson and co-workers, apparently the phagocytes of the liver are unable to handle all the particles passing through the liver capillaries in a given time.

It may, therefore, be advisable not to increase the quantity of colloidal gold over $250 \mu \mathrm{gm}$. This has not been done in the studies reported below. In fact, most of the subjects studied were given quantities below $100 \mu \mathrm{gm}$.

\section{Efficiency of removal}

It is clearly essential to determine to what extent the liver phagocytes are capable of clearing the blood passing through the capillaries completely of all the particles within a single passage. If this is the case the disappearance rate constant should then represent the fraction of blood volume perfusing the liver per unit time and, if the blood 


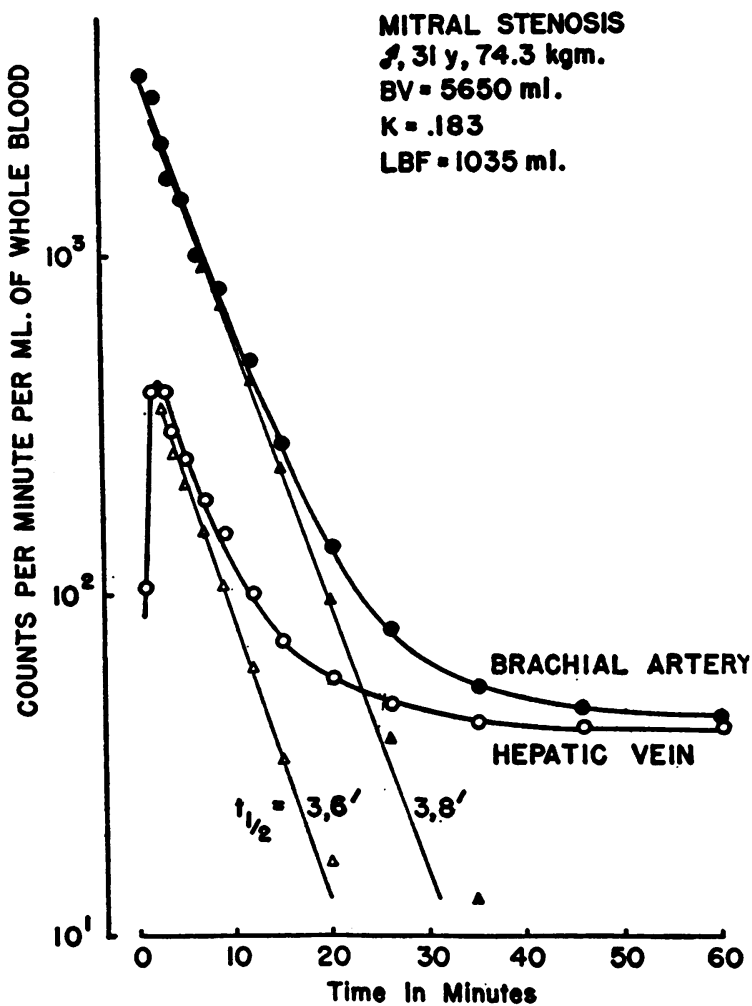

Fig. 1. Radiogold Concentrations in Hepatic Vein and Brachial Artery Blood Following Intravenous Injection of Colloidal Radiogold in a Case of Mitral Stenosis with Slightly Elevated Pulmonary Artery Pressures but Without Evidence of Cardiac FaIlure

The fastest component of both curves have been separated graphically by successive subtraction of the slower components from the actual values. The decrease in radioactivity is due to the removal of the large and medium-sized particles by the liver phagocytes. In this case, about 13 per cent of the particles passed the liver without having been picked up during the first passage. As the fraction of very small particles increases with time, liver vein and peripheral activity equal each other.

volume is known, the liver blood flow per minute can be calculated.

To investigate the efficiency of removal of the particles a Cournand catheter was placed into a right liver vein by the usual technic in three patients (one with and two without impaired liver cell function), and serial blood samples were taken from there as well as from the brachial artery. Allowance was made for the delay in appearance of the hepatic vein blood at the other end of the catheter. During the first five minutes following the injection the ratio of the radiogold concentrations of the hepatic vein to the brachial artery blood at the same time was found to be constant with values of 13,22 , and 19 per cent, respectively. The average value of about 18 per cent is in striking agreement with the results of animal experiments done with chromic phosphate (8) and with those of liver perfusion experiments with radiogold performed by Little and Kelly (9).

This ratio increases with time due to the relative increase of very small particles still present in the circulation and presumably never to be picked up by the reticulo-endothelial cells of the liver. At the end of one hour following injection the radioactivity in the hepatic vein samples almost equals that in peripheral blood. If the usual corrections are applied to both disappearance curves, then the first and fastest components of both curves run parallel to each other (Figure 1).

These results would indicate that the colloid disappearance methods regardless of the type of particulate matter used, underestimate the liver blood flow by almost 20 per cent, and that they measure a minimal rather than the true liver blood flow.

\section{The disappearance rate constant in normal subjects}

Eighteen male and seven female patients without any apparent liver or circulatory disorders were selected for determinations of the colloidal radiogold disappearance rate and calculations of minimal liver blood flow, the results of which are presented in Table IV. Hematocrits, plasma volumes (Mean : $43.5 \mathrm{ml}$. per $\mathrm{Kg}$.), and blood volumes could be considered to be normal. It should be noted that there was a wide distribution of body weights.

\section{The disappearance rate constant in liver cirrhosis}

- Colloid disappearance rates were determined and minimal liver blood flows were calculated in 12 patients - 10 males and 2 females - and the results are given in Table V. According to their laboratory findings (galactose excretion, thymol turbidity, zinc sulfate turbidity, alkaline phosphatase, cephalin flocculation, prothrombin time, bromsulphalein-clearance and -retention, serum protein electrophoresis) and to the clinical picture, all patients were suffering from marked 
HERBERT VETTER, RUDOLF FALKNER, AND ANTON NEUMAYR

TABLE IV

Date on blood volume, disappearance rate constant, and minimal liver blood flow from 18 male and 7 female patients without apparent liver or circulatory disorders

\begin{tabular}{|c|c|c|c|c|c|c|c|c|c|}
\hline \multirow[b]{2}{*}{ Case } & \multirow[b]{2}{*}{ Name } & \multirow{2}{*}{$\begin{array}{l}\text { Weight } \\
\left(K_{\ell}\right)\end{array}$} & \multirow{2}{*}{$\begin{array}{c}\text { Corr. ven. } \\
\text { hematocr. } \\
(\%)\end{array}$} & \multirow{2}{*}{$\begin{array}{c}\text { Plasma } \\
\text { volume } \\
(m l .)\end{array}$} & \multicolumn{2}{|c|}{ Blood volume } & \multirow{2}{*}{$\begin{array}{l}\text { Disappear. } \\
\text { rate const. } \\
\left(\min .^{-1}\right)\end{array}$} & \multicolumn{2}{|c|}{ Liver blood flow } \\
\hline & & & & & $(m l)$. & $\left(m l_{.} / K_{g .}\right)$ & & $(m l)$. & $\left(m l_{0} / K_{g}\right)$ \\
\hline \multicolumn{10}{|c|}{ Males } \\
\hline $\begin{array}{r}1 \\
2 \\
3 \\
4 \\
5 \\
6 \\
7 \\
8 \\
9 \\
10 \\
11 \\
12 \\
13 \\
14 \\
15 \\
16 \\
17 \\
18\end{array}$ & $\begin{array}{l}\text { SCHW } \\
\text { BAR } \\
\text { KAR } \\
\text { LAC } \\
\text { LEI } \\
\text { WEN } \\
\text { KRA } \\
\text { BER } \\
\text { NIK } \\
\text { LUK } \\
\text { MIT } \\
\text { WAW } \\
\text { MOD } \\
\text { ASB } \\
\text { MUL } \\
\text { STO } \\
\text { SCHU } \\
\text { MAD }\end{array}$ & $\begin{array}{l}95.7 \\
69.5 \\
73.6 \\
70.5 \\
73.5 \\
70.9 \\
84.5 \\
96.2 \\
90.2 \\
87.2 \\
73.3 \\
64.9 \\
59.5 \\
60.5 \\
52.3 \\
87.9 \\
51.0 \\
77.1\end{array}$ & $\begin{array}{l}44.1 \\
46.7 \\
43.0 \\
46.9 \\
50.0 \\
39.7 \\
44.0 \\
41.0 \\
46.8 \\
45.3 \\
40.6 \\
40.4 \\
40.5 \\
44.9 \\
38.2 \\
39.4 \\
41.6 \\
42.0\end{array}$ & $\begin{array}{l}4,580 \\
3,070 \\
3,360 \\
3,540 \\
2,970 \\
3,070 \\
3,190 \\
4,750 \\
3,910 \\
3,340 \\
3,830 \\
2,860 \\
2,920 \\
2,260 \\
2,680 \\
3,550 \\
2,790 \\
3,220\end{array}$ & $\begin{array}{l}7,650 \\
5,350 \\
5,520 \\
6,180 \\
5,450 \\
4,810 \\
5,310 \\
7,590 \\
6,800 \\
5,860 \\
6,080 \\
4,520 \\
4,620 \\
3,820 \\
4,100 \\
5,530 \\
4,490 \\
5,210\end{array}$ & $\begin{array}{l}79.9 \\
77.0 \\
75.0 \\
82.6 \\
74.1 \\
68.0 \\
63.0 \\
78.8 \\
75.4 \\
67.4 \\
83.0 \\
69.8 \\
77.7 \\
63.1 \\
78.5 \\
62.9 \\
78.8 \\
67.8\end{array}$ & $\begin{array}{l}.178 \\
.210 \\
.227 \\
.227 \\
.243 \\
.248 \\
.248 \\
.252 \\
.252 \\
.256 \\
.256 \\
.289 \\
.289 \\
.301 \\
.308 \\
.322 \\
.356 \\
.385\end{array}$ & $\begin{array}{l}1,360 \\
1,120 \\
1,255 \\
1,405 \\
1,320 \\
1,195 \\
1,320 \\
1,910 \\
1,710 \\
1,500 \\
1,560 \\
1,305 \\
1,380 \\
1,150 \\
1,260 \\
1,780 \\
1,600 \\
2,010\end{array}$ & $\begin{array}{l}14.2 \\
16.1 \\
17.0 \\
19.9 \\
15.6 \\
16.8 \\
15.6 \\
19.9 \\
19.0 \\
17.2 \\
21.3 \\
20.2 \\
23.2 \\
19.0 \\
24.1 \\
20.2 \\
28.1 \\
26.1\end{array}$ \\
\hline $\begin{array}{l}\text { Mean } \\
\pm(\mathbf{M})\end{array}$ & & 74.7 & & & & 73.5 & $\begin{array}{l}.269 \\
.012\end{array}$ & 1,425 & $\begin{array}{r}19.5 \\
0.9\end{array}$ \\
\hline \multicolumn{10}{|c|}{ Females } \\
\hline $\begin{array}{l}1 \\
2 \\
3 \\
4 \\
5 \\
6 \\
7\end{array}$ & $\begin{array}{l}\text { PRO } \\
\text { SIC } \\
\text { GAM } \\
\text { NOT } \\
\text { ALB } \\
\text { ENE } \\
\text { TSC }\end{array}$ & $\begin{array}{l}42.6 \\
66.5 \\
70.4 \\
46.5 \\
55.2 \\
54.6 \\
67.3\end{array}$ & $\begin{array}{l}36.1 \\
42.5 \\
38.2 \\
39.9 \\
39.6 \\
40.1 \\
41.1\end{array}$ & $\begin{array}{l}2,170 \\
2,940 \\
2,980 \\
2,080 \\
2,480 \\
2,810 \\
2,960\end{array}$ & $\begin{array}{l}3,230 \\
4,800 \\
4,570 \\
3,270 \\
3,880 \\
4,420 \\
4,720\end{array}$ & $\begin{array}{l}75.8 \\
72.1 \\
64.9 \\
70.3 \\
70.3 \\
80.1 \\
70.2\end{array}$ & $\begin{array}{l}.193 \\
.213 \\
.213 \\
.224 \\
.267 \\
.283 \\
.301\end{array}$ & $\begin{array}{r}625 \\
1,020 \\
975 \\
735 \\
1,035 \\
1,250 \\
1,420\end{array}$ & $\begin{array}{l}14.7 \\
15.4 \\
13.9 \\
15.8 \\
18.7 \\
22.9 \\
21.1\end{array}$ \\
\hline $\begin{array}{l}\text { Mean } \\
\pm(M)\end{array}$ & & 57.6 & & & & 71.9 & $\begin{array}{l}.242 \\
.059\end{array}$ & 1,010 & $\begin{array}{r}17.5 \\
4.1\end{array}$ \\
\hline \multicolumn{10}{|c|}{ Males and Females } \\
\hline $\begin{array}{l}\text { Mean } \\
\pm(\mathbf{M})\end{array}$ & & 69.9 & & & & 73.1 & $\begin{array}{l}.262 \\
.010\end{array}$ & 1,310 & $\begin{array}{r}19.0 \\
0.8\end{array}$ \\
\hline
\end{tabular}

cirrhosis of the liver, most of them presenting an outspoken history of chronic alcoholism. However, in none of the patients could appreciable amounts of free abdominal fluid be demonstrated.

\section{DISCUSSION}

An evaluation of the usefulness of the colloid disappearance rate as a tool in the diagnosis of liver and circulatory disorders would have to concentrate on the following questions :

1. Does the disappearance rate reflect the state of liver circulation or is it affected by factors pri- marily unrelated to liver blood flow, e.g., the function of the liver cell?

2. If there are such factors, is the degree of their influence on the disappearance rate dependent on the type or intensity of the liver or circulatory disorder present?

3. If it should appear to be justified to take the disappearance rate as a parameter of the state of liver circulation, is the present technic reliable and simple enough in order that it could be introduced as a routine clinical procedure?

1. If this method should permit an estimation of liver blood flow then the values obtained in 
TABLE V

Data on blood volume, disappearance rate constant, and minimal liver blood flow from 10 male and 2 female patients with liver cirrhosis

\begin{tabular}{|c|c|c|c|c|c|c|c|c|c|}
\hline \multirow[b]{2}{*}{ Case } & \multirow[b]{2}{*}{ Name } & \multirow{2}{*}{$\underset{\left(K_{\ell}\right)}{\text { Weight }}$} & \multirow{2}{*}{$\begin{array}{c}\text { Corr. ven. } \\
\text { hematocr. } \\
(\%)\end{array}$} & \multirow{2}{*}{$\begin{array}{c}\text { Plasma } \\
\text { volume } \\
(m l .)\end{array}$} & \multicolumn{2}{|c|}{ Blood volume } & \multirow{2}{*}{$\begin{array}{l}\text { Disappear. } \\
\text { rate const. } \\
\left(\min .^{-1}\right)\end{array}$} & \multicolumn{2}{|c|}{ Liver blood flow } \\
\hline & & & & & $(m l)$. & $\left(m l_{.} / K_{\mathbf{g} .}\right)$ & & $(m l)$. & $(m l . / K g)$. \\
\hline \multicolumn{10}{|c|}{ Males } \\
\hline $\begin{array}{r}1 \\
2 \\
3 \\
4 \\
5 \\
6 \\
7 \\
8 \\
9 \\
10\end{array}$ & $\begin{array}{l}\text { EIC } \\
\text { SCHI } \\
\text { MAL } \\
\text { KUM } \\
\text { SEJ } \\
\text { STE } \\
\text { SIE } \\
\text { POS } \\
\text { WAY } \\
\text { ZIE }\end{array}$ & $\begin{array}{l}67.5 \\
67.1 \\
59.5 \\
65.5 \\
64.9 \\
60.5 \\
71.4 \\
84.1 \\
63.0 \\
55.0\end{array}$ & $\begin{array}{l}30.2 \\
42.5 \\
29.6 \\
40.0 \\
38.3 \\
43.0 \\
43.6 \\
38.2 \\
35.6 \\
35.0\end{array}$ & $\begin{array}{l}4,450 \\
3,220 \\
3,440 \\
3,620 \\
4,280 \\
3,610 \\
3,420 \\
4,330 \\
3,540 \\
2,925\end{array}$ & $\begin{array}{l}\mathbf{6}, 140 \\
\mathbf{5 , 2 5 0} \\
4,710 \\
\mathbf{5 , 6 9 0} \\
\mathbf{6 , 5 6 0} \\
\mathbf{5 , 9 4 0} \\
5,670 \\
\mathbf{6 , 6 4 0} \\
\mathbf{5 , 2 4 0} \\
4,290\end{array}$ & $\begin{array}{r}91.0 \\
78.0 \\
79.3 \\
84.6 \\
101.1 \\
98.1 \\
79.8 \\
77.8 \\
83.1 \\
78.0\end{array}$ & $\begin{array}{l}.051 \\
.066 \\
.074 \\
.081 \\
.084 \\
.086 \\
.107 \\
.117 \\
.131 \\
.143\end{array}$ & $\begin{array}{l}315 \\
345 \\
350 \\
460 \\
550 \\
510 \\
605 \\
775 \\
685 \\
610\end{array}$ & $\begin{array}{c}4.65 \\
5.15 \\
5.9 \\
6.85 \\
8.45 \\
8.45 \\
8.5 \\
9.25 \\
10.9 \\
11.1\end{array}$ \\
\hline Mean & & 65.9 & & & & 85.1 & .094 & 520 & 7.92 \\
\hline \multicolumn{10}{|c|}{ Females } \\
\hline $\begin{array}{l}1 \\
2\end{array}$ & $\begin{array}{l}\text { PRA } \\
\text { HOF }\end{array}$ & $\begin{array}{l}95.4 \\
49.6\end{array}$ & $\begin{array}{l}43.0 \\
35.2\end{array}$ & $\begin{array}{l}3,920 \\
3,020\end{array}$ & $\begin{array}{l}6,450 \\
4,450\end{array}$ & $\begin{array}{l}67.6 \\
89.6\end{array}$ & $\begin{array}{l}.076 \\
.129\end{array}$ & $\begin{array}{l}490 \\
575\end{array}$ & $\begin{array}{l}5.15 \\
11.6\end{array}$ \\
\hline Mean & & 72.5 & & & & 78.6 & .103 & 535 & 8.38 \\
\hline \multicolumn{10}{|c|}{ Males and Females } \\
\hline Mean & & 66.9 & & & & 84.0 & .095 & 525 & 8.0 \\
\hline
\end{tabular}

normals should, at least to a certain extent, agree with values already obtained by other methods whose accuracy has been reasonably established. That this is the case is shown in Table VI where several data are listed for convenience of comparison. It may be calculated that the average of all data obtained with the bromsulphalein method in normal men and women is about $1410 \mathrm{ml}$. per min., which is only about $100 \mathrm{ml}$. per min. higher than the average of the radiogold results. Furthermore, the average value of $19.0 \mathrm{ml}$. per min. per $\mathrm{Kg}$. body weight is certainly within the range of the data reported by other groups. This despite the fact that we are bound to assume that the colloid methods underestimate the liver blood flow to an appreciable extent.

The radiogold results in cirrhotic patients are in agreement with the data previously given by

TABLE VI

Average normal liver blood flow values given by various authors

\begin{tabular}{|c|c|c|c|c|c|}
\hline Authors & Ref. & Sex & $\begin{array}{l}\text { Number } \\
\text { of cases }\end{array}$ & $\underset{\text { (ml./min.) }}{\text { LBF }}$ & Method used \\
\hline $\begin{array}{l}\text { Bradley, Ingelfinger, Bradley, and Curry } \\
\text { Bradley } \\
\text { Bradley, Ingelfinger, and Bradley } \\
\text { Sherlock, Bearn, Billing, and Paterson } \\
\text { Wilkins, Culbertson, and Rymut } \\
\text { Shackman, Graber, and Melrose } \\
\text { Myers } \\
\text { Bondy, James, and Farrar } \\
\text { Dobson, Warner, Finney, and Johnston }\end{array}$ & $\begin{array}{r}(1) \\
(10) \\
(11) \\
(12) \\
(13) \\
(14) \\
(15) \\
(16) \\
(3)\end{array}$ & $\begin{array}{l}\text { M, F } \\
\mathbf{M} \\
\mathbf{M} \\
\mathbf{M}, \mathbf{F} \\
\mathbf{M}, \mathbf{F} \\
\mathbf{M}, \mathbf{F} \\
\mathbf{M}, \mathbf{F} \\
\mathbf{M}, \mathbf{F} \\
\mathbf{M}, \mathbf{F}\end{array}$ & $\begin{array}{r}23 \\
50 \\
73 \\
32 \\
21 \\
18 \\
9 \\
10 \\
7 \\
29\end{array}$ & $\begin{array}{l}1,510 \\
1,490 \\
1,580 \\
1,400 \\
1,380 \\
1,260 \\
1,390 \\
1,780 \\
1,470 \\
1,790\end{array}$ & $\begin{array}{c}\text { BSP } \\
\text { BSP } \\
\text { BSP } \\
\text { BSP } \\
\text { BSP } \\
\text { BSP } \\
\text { BSP } \\
\text { Urea } \\
\text { BSP and urea } \\
\text { Chromic phosphate }\end{array}$ \\
\hline Present authors & & $\underset{\mathbf{F}}{\mathbf{M}}$ & $\begin{array}{c}18 \\
7\end{array}$ & $\begin{array}{l}1,425 \\
1,010\end{array}$ & $\begin{array}{l}\text { Colloidal gold } \\
\text { Colloidal gold }\end{array}$ \\
\hline
\end{tabular}


Bradley, Ingelfinger, and Bradley (11) in men and by Bollman, Khattab, Thors, and Grindlay (17) in dogs. In some instances they are even considerably lower.

There remains the possibility that not only the function of the liver cells but also the removing ability of the phagocytes is impaired in liver disease; however, we are not aware of any conclusive evidence in the literature which would prove this point. In separate experiments the results of which have been published elsewhere (18) we have carefully compared the blood clearance rates of colloidal radiogold and of bromsulphalein in patients with various degrees of liver cirrhosis. Though the clearance of bromsulphalein is, of course, strongly dependent on liver blood flow it also depends on liver cell function. If the colloid clearance depended on liver cell function some correlation between the two clearance rates might have been expected. However, no correlation at all was found. It has been even possible to define an "extraction factor" of bromsulphalein by calculating the ratio of the amounts of blood which are cleared by both substances per minute, in order to eliminate the influence of liver blood flow on the bromsulphalein clearance and thereby to obtain a clearer indication of the function of the liver cells. This factor showed large variations with varying degrees of cirrhosis and it is, therefore, highly probable that phagocyte function and liver cell function are independent of each other. Moreover, the inability to handle large amounts of particulate material was equally shared by normal subjects and cases with impaired liver cell function (Table III), and in the group of patients who were subjected to catheterization studies the case who showed the highest efficiency of removal was that whose liver function was definitely impaired.

2. Apart from the factor of removal efficiency of the phagocytes there is, however, another factor whose significance is rather difficult to assess. An underestimation of liver blood flow might also result from the presence of arterio-venous or veno-venous anastomoses through which a certain fraction of the blood entering the hepatic circulation might by-pass the liver capillaries. This factor might be quite dependent on the intensity of the liver disorder. It is, for instance, fairly conceivable that the magnitude of these shunts is considerably increased in the presence of liver cirrhosis (19) and that, therefore, liver blood flow in such cases is grossly underestimated by the colloid methods. It should be noted, however, that these objections are also valid with methods like the bromsulphalein technic which are based on the Fick principle.

3. Assuming that the colloid disappearance rate reflects the state of liver circulation this
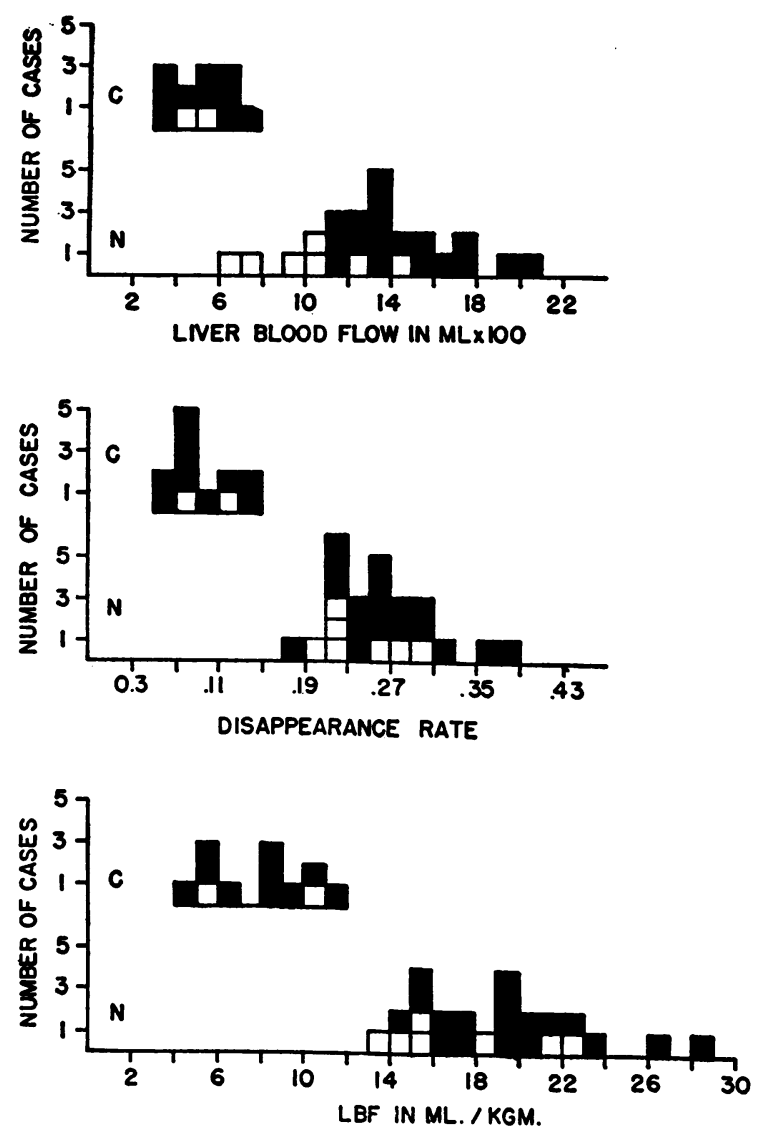

Fig. 2. Comparison of the Results Obtained in Normal (N) and Cirrhotic (C) Patients Expressed IN THREe Ways

There is a considerable overlap between both groups when the minimal liver blood flows are expressed in terms of absolute flows. The average minimal liver blood flow in female subjects (open squares) is smaller than in males (full squares) because of their smaller blood volume. A satisfactory separation between normal and cirrhotic values can be achieved by either relating the absolute amounts of flow to body weight or by simply using the disappearance rate constants. Large individual variations are observed but there is now no significant difference between normal male and female subjects. 
method should be able to provide clinically useful results. Dobson and coworkers have pointed out that the disappearance rate constant is a more convenient term for describing the state of hepatic circulation than the quantitative flow expressed in liter per minute. This view is confirmed by the present observations. In normal subjects with small blood volumes very often liver blood flows below $1000 \mathrm{ml}$. per min. may be encountered, and this tends to obscure the significance of low values found in cases with liver disease. Relating the liver blood flow to either body weight or body surface area leads to a better separation between values obtained in normal and cirrhotic patients; however, the separation between the disappearance rate constants is equally satisfactory (Figure 2), and the scatter in normal subjects is about the same (Table IV). It is, therefore, felt that the method of estimating liver blood flow and then expressing it in terms per $\mathrm{Kg}$. body weight or $\mathrm{m}^{2}$. surface area does not constitute any considerable advantage over the use of the disappearance rate constant alone. On the contrary, the omission of blood volume determination would further simplify the procedure to a considerable extent.

It appears from the rough agreement between the averages of disappearance rate constants obtained with chromic phosphate and with colloidal gold that the factor of particle size does not play that important role which was ascribed to it by Dobson and Jones (8). This was to be expected from the data published by Zilversmit, Boyd, and Brucer (20). It was shown by this group that very small particles are, indeed, very slowly removed from the circulation but that the decrease in clearance times is very small when particles larger than $270 \AA$ in diameter are used. Moreover, the effect of the small fraction of minute particles in the preparation on the disappearance curve is, in any case, corrected for by the graphical separation of the fastest component. Therefore, the use of a preparation like the chromic phosphate colloid which is so difficult and timeconsuming to produce, is most probably not essential for the accuracy of this method. The small difference in the averages of both colloid disappearance rates might well be due to the fact that we were unable to assemble such a satisfactory group of young men between 21 and 26 years of age in an apparently enviable state of health.

With the present amount of radiogold injected ( 50 to $100 \mu \mathrm{c}$.) not more than 5 rep. are delivered to the liver or spleen. In fact, several hundred times this dose of $\mathrm{Au}^{198}$ had been administered in this laboratory to patients with chronic myelocytic leukemia without any subsequent impairment of liver function (21). The radiation dose could be even further reduced by using a more sensitive counting equipment, such as encircling one of the patient's legs with a multiple counter arrangement of the type which has been developed by Veall, Vetter, and Baptista $(22,23)$.

Colloidal gold with a suitable particle size and a high specific activity is available in large quantities which in most hospitals where radioisotopes are used, are always more or less on stock for therapeutic purposes. Being a $\gamma$-emitter, it permits convenient determination of its removal rate from outside the body. The procedure is fairly simple and could even be more simplified by the use of a logarithmic counting rate meter in combination with an automatic recording instrument.

In conclusion, it appears in the light of present knowledge that the colloid disappearance rate is, to a large extent, related to the state of liver circulation. The actual value of liver blood flow calculated from the disappearance rate constant and the blood volume must be treated with reserve, in view of the fact that the liver does not clear the blood completely in a single passage. However, its inaccuracy is probably not greater than that of other methods currently in use for the estimation of various hemodynamic data, such as cardiac output or renal blood flow. The procedure of determining the colloid disappearance rate is simple, reliable, and harmless to the patient.

\section{SUM MARY}

1. The disappearance rate of small amounts of colloidal radioactive gold has been used to calculate the minimal fraction of the blood volume perfusing the liver per minute.

2. The average value for the disappearance rate constant obtained in 18 normal men was 0.269 and in 7 normal women 0.242 min. $^{-1}$, correspond- 
ing to an average minimal liver blood flow of 1425 and $1010 \mathrm{ml}$. per min., respectively.

3. In 12 cirrhotic patients a grossly diminished disappearance rate was observed.

4. The results of several experiments carried out in order to determine the reliability and accuracy of this method have been discussed.

\section{REFERENCES}

1. Bradley, S. E., Ingelfinger, F. J., Bradley, G. P., and Curry, J. J., The estimation of hepatic blood flow in man. J. Clin. Invest., 1945, 24, 890.

2. Sheppard, C. W., Jordan, G., and Hahn, P. F., Disappearance of isotopically labeled gold colloids from the circulation of the dog. Am. J. Physiol., 1951, 164, 345.

3. Dobson, E. L., Warner, G. F., Finney, C. R., and Johnston, M. E., The measurement of liver circulation by means of the colloid disappearance rate. I. Liver blood flow in normal young men. Circulation, 1953, 7, 690.

4. Falkner, R., Neumayr, A., and Vetter, H., Die Bestimmung des Blutflusses durch die Leber mit kolloidalem Radiogold. Symposium on clinical applications of radioactive isotopes, Bad Gastein, January 1954, Strahlenther., in press.

5. Veall, N., A Geiger-Muller counter for measuring the beta-ray activity of liquids, and its application to medical tracer experiments. Brit. J. Radiol., 1948, 21, 347.

6. Chaplin, H., Jr., and Mollison, P. L., Correction for plasma trapped in the red cell column of the hematocrit. Blood, 1952, 7, 1227.

7. Chaplin, H., Jr., Mollison, P. L., and Vetter, H., The body/venous hematocrit ratio: its constancy over a wide hematocrit range. J. Clin. Invest., 1953, 32, 1309.

8. Dobson, E. L., and Jones, H. B., The behavior of intravenously injected particulate material: its rate of disappearance from the blood stream as a measure of liver blood flow. Acta med. Scandinav., 1952, 144, suppl. 273.

9. Little, R. C., and Kelly, H. B., Removal of radioactive gold colloid by the perfused mammalian liver. Am. J. Physiol., 1953, 173, 265.

10. Bradley, S. E., Variations in hepatic blood flow in man during health and disease. New England J. Med., 1949, 240, 456.
11. Bradley, S. E., Ingelfinger, F. J., and Bradley, G. P., Hepatic circulation in cirrhosis of the liver. Cir: culation, 1952, 5, 419.

12. Sherlock, S., Bearn, A. G., Billing, B. H., and Paterson, J. C. S., Splanchnic blood flow in man by the bromsulfalein method: the relation of peripheral plasma bromsulfalein level to the calculated flow. J. Lab. \& Clin. Med., 1950, 35, 923.

13. Wilkins, R. W., Culbertson, J. W., and Rymut, A. A., The hepatic blood flow in resting hypertensive patients before and after splanchnicectomy. J. Clin. Imvest., 1952, 31, 529.

14. Shackman, R, Graber, I. G., and Melrose, D. G., Liver blood flow and general anaesthesia. Clin. Sc., 1953, 12, 307.

15. Myers, J. D., The hepatic blood flow and splanchnic oxygen consumption of man-their estimation from urea production or bromsulphalein excretion during catheterization of the hepatic veins. J. Clin. Invest., 1947, 26, 1130.

16. Bondy, P. K., James, D. F., and Farrar, B. W., Studies of the role of the liver in human carbohydrate metabolism by the venous catheter technic. I. Normal subjects under fasting conditions and following the injection of glucose. J. Clin. Invest., 1949, 28, 238.

17. Bollman, J. L., Khattab, M., Thors, R., and Grindlay, J. H., Experimentally produced alterations of hepatic blood flow. Arch. Surg., 1953, 66, 562.

18. Neumayr, A., Parzer, O., and Vetter, H., Zur Problematik der Bromsulphalein-Clearance als Leberfunktionsprüfung. Deutsche Med. Wchnschr., 1954, 79, 1039.

19. Berman, J. K., and Hull, J. E., Circulation in the normal and cirrhotic liver. Ann. Surg., 1953, 137, 424.

20. Zilversmit, D. B., Boyd, G. A., and Brucer, M., The effect of particle size on blood clearance and tissue distribution of radioactive gold colloids. J. Lab. \& Clin. Med., 1952, 40, 255.

21. Fellinger, $\mathrm{K}$., and Vetter, $\mathrm{H}$., Radiogoldtherapie der leukaemischen Erkrankungen. Symposium on clinical applications of radioactive isotopes, $\mathrm{Bad}$ Gastein, January 1954, Strahlenther., In press.

22. Veall, N., and Vetter, H., An apparatus for the rapid estimation of tracer quantities of radioactive isotopes in excreta. Brit. J. Radiol., 1952, 25, 85.

23. Veall, N., and Baptista, A. M., A multi-tube gamma counting apparatus for small samples. Brit. J. Radiol., 1954, 27, 198. 